\title{
Domestic schools of architectural restoration in the XX century
}

\author{
Aleksandr Shumilkin ${ }^{1, *}$ \\ ${ }^{1}$ Nizhny Novgorod State University of Architecture and Civil Engineering, 603000, 65, Ilyinskaya st., \\ Nizhny Novgorod, Russia
}

\begin{abstract}
One of the aspects of the development of Russian architectural restoration in the twentieth century was the selection and formation of regional architectural restoration schools. The purpose of the study: to identify the features of the leading schools of Russian architectural restoration in the twentieth century. Methods: a comprehensive study, comparative analysis of architectural and restoration practices of Moscow, Novgorod, Vladimir-Suzdal, Leningrad, Pskov restoration schools based on the generalization of bibliographic material. Results: the role of architectural and restoration schools in the development of scientific theory and practice of restoration in the twentieth century is Revealed.the features of restoration techniques and methodological approaches of Moscow, Novgorod, Vladimir-Suzdal, Leningrad, Pskov restoration schools are Analyzed. The influence of the typological and architectural and artistic context, the degree of its preservation, on the specifics of architectural and restoration activities of individual schools is revealed. The prevailing types of restoration (integral, fragmentary, compromise, synthetic) at the main stages of formation of domestic restoration schools are determined.
\end{abstract}

\section{Introduction}

The study of architectural and restoration schools of the twentieth century is a separate area of fundamental research in the theory and practice of national restoration. A qualitatively new level of consideration of this problem is given in a collective monographic work devoted to architectural monuments in the Soviet period [1]. It is important to understand Russian restoration views and approaches in the context of European trends in architectural restoration in the second half of the twentieth century [2-3]. General regularities and trends of restoration activity in the aspect of a wide range of monuments of architecture and art are considered in the works of $\mathrm{Yu}$. Bobrov [4-5]. The research raises the problem of continuity and contradiction of methodological principles, including those formed within the framework of individual restoration schools of the second half of the twentieth century, and modern trends in working with monuments [1]. The problems related to the refraction of traditional restoration approaches in the context of modern problems of preserving monuments are reflected in the works of B. Matveev [6].

There is a range of studies that cover in sufficient detail the stages of the formation of individual large restoration workshops. One of the large-scale scientific works is devoted to

\footnotetext{
${ }^{*}$ Corresponding author: ist_arh@nngasu.ru
} 
a review of the theory and practice of the Vladimir-Suzdal restoration school, reflecting its history, principles and methods using examples of restoration of the most significant monuments [7]. A major work is the publication devoted to the activities of the Moscow Central Scientific and Restoration Workshops. The book on the Leningrad school of restoration, based on extensive practical material, analyzes the main approaches, principles, methods and types of restoration work on monuments and architectural and urban planning ensembles [8]. A number of articles present a modern view of the history of the formation of the Leningrad restoration school [9-10]. The influence of the principles of the Leningrad school, in particular, the principle of post-war holistic restoration, is considered in the aspect of modern trends in the reconstruction and reconstruction of monuments [11]. The activities of the Novgorod restoration school were largely covered and analyzed [12], the practice of Novgorod restoration at the turn of the 20th - 21st centuries was generalize [13]. Studies appear reflecting the restoration practice of the 20th - early 21 st centuries. in certain regions [14]. A number of scientific articles by the author are devoted to identifying the features of domestic schools of architectural restoration of the twentieth century. [15]. In the framework of this study, a step is being made towards a comprehensive systematic analysis of the features of architectural and restoration schools established in certain regions of the country in the 20th century

\section{Materials and Methods}

The formation of architectural and restoration schools in the twentieth century. the need for a large-scale restoration of the unique historical and urban heritage of the country's regions in the post-war period served. Creation by the beginning of the 1950s. the network of restoration workshops in major historical cities led to the differentiation of national restoration activities with the allocation of individual restoration schools that developed in line with their own architectural practice. In this study, we dwell on the study of the leading architectural and restoration schools of the twentieth century: Moscow, Novgorod, Vladimir-Suzdal, Leningrad, Pskov.

The development of the Moscow restoration school was based on the tradition laid down by the Moscow Archaeological Society (A.S. Uvarov), the Commission for the Preservation of Ancient Monuments, and the Imperial Archaeological Commission. In the post-revolutionary period, the development of the national school of restoration was associated with the work of the Central State Restoration Workshops, which concentrated the restoration forces of several institutions of the country. The development of the Moscow restoration school received a new impetus with the creation in 1947 of the Central Design Restoration Workshop, which became the leading restoration organization in the country [16]. A similar base formed the features of the Moscow restoration school, its practical approaches, combined with the development of the scientific and methodological direction and basic research. The Moscow workshop developed the main methodological approaches and restoration techniques, which later spread to regional schools.

Restoration work on Moscow monuments has traditionally been characterized by increased controversy, accompanied by a confrontation of mutually exclusive methodological approaches. The general tendency of the Moscow restoration was the focus on identifying the original forms, combined with attention to individual historical layers, the desire for minimal disruption by hypothetical alterations of the existing structure. The monuments mainly had a complex complex character: many buildings consisted of the original ancient core and later extensions of various periods. The condition of the monuments that were not destroyed during the war period, by the time of restoration was often extremely difficult due to unacceptable conditions for their operation. A significant number of religious buildings had the loss and destruction of the crowning parts (drums, chapters), which reduced their architectural and compositional value and distorted the 
semantic appearance. During the restoration, the question of "recomposition" of completions was decided on the basis of the analysis of proportional ratios, comparison of the remains of genuine fragments, attraction of possible analogues (Tryphon Church in Naprudnaya, 1947 - 1953, architect L.A. David).

The attitude to the late stratifications of various periods, the historical, cultural and artistic significance of which was interpreted depending on the degree of their antiquity, was ambiguous. So, during the restoration of the Church of the Conception of Anna (XVI century), the later extensions of the XVII century. were preserved and restored, at the same time, the layers of the XVIII - XIX centuries. removed as elements that violate the integrity of the composition of the monument (restoration of 1954 - 1958, architect L.A. David). In general, restoration approaches of the 1940s - 1950s. On the monuments of old Russian architecture of Moscow they reflected the installation of recreation for a certain optimal date, a predominant orientation towards restoring the original forms, the stylistic community of the ancient core and late layers.

Similar principles aimed at discovering and restoring the original forms with the extensive use of recreations by analogs were also applied in the restoration of monuments of classicism. The concept of "analogue" in practice was interpreted very broadly, it was allowed to recreate details in the general style of the monument or typological analogues (restoration of the house of AS Griboedov, architect M.F. Fechner).

In the practice of Moscow restoration of the 1960s. Fragmentary approaches assumed the significant role, the supposed combination of elements that had never been discovered before in the form of a monument. With a general focus on the full restoration of the original appearance of the monument, in-depth research and implementation of the work, the choice was often made in favor of fragmentary restorations (the Nativity Cathedral of the early 16th century. Rozhdestvensky Monastery, restoration of 1968, architect N.V. Ilyenkova). This method was recognized as appropriate in cases where the nature of the construction of individual forms of the monument (gulbishche, stairs) remained unclear and reliable restoration of its original appearance was not possible. The basic principle remained the desire to minimize the replacement of ancient material with new in terms of white stone and brick decor, masonry, metal elements. Nevertheless, in order to restore the artistic appearance of the monument, new elements were introduced into the place of individual lost details, original methods for their fastening were developed (the Resurrection Church in Kadashi at the end of the 17th century, restoration of 1957-1958, author of the project G.V. Alferova). In the 1960s Complicated works of the Moscow school appeared, combining fragmentary restoration with the preservation of late layers and reconstructing by analogy (the Cathedral of the Znamensky Monastery of the 17th century, restoration of 1966, architect E.P. Zhavoronkova). The priority of functional use has also become an important argument in favor of fragmented restorations.

The birth of the Novgorod school of architectural restoration was in the early 20th century. - The period of the most important restoration work. In the $1900-1910$ s. Novgorod was one of the main centers of scientific restoration of architecture. Stage 1920 1930s associated with the activities of famous architects and researchers, representatives of St. Petersburg and Moscow scientific schools. The pre-war period can be seen as the foundation upon which the brilliant post-war Novgorod restoration grew, reaching its "golden age" in the 1950s and 1960s.

Novgorod had more significant damage relative to other occupied cities, which predetermined the conservation nature of the work of the 1940s. The most significant or affected monuments within the city were given priority, mainly with valuable artistic interiors. In connection with the main direction of conservation activity, original engineering solutions and structures for the restoration and strengthening of ancient monuments were developed (restoration of the house at Zvonnitsa, 1945, architect V.N. Zakharova). 
By the early 1950s the first full-fledged work was carried out, which laid the practice of compromise restorations, when forms of several periods were restored on one monument (the Church of Dmitry Solunsky, restoration 1947 - 1950, architect L.M. Shulyak). Stage 1950 - 1960s associated with the transition to full-fledged comprehensive restoration of the most famous monuments. Most of the works belonged to the type of analytical restorations based on the analysis of field data. Some of the works demonstrated an example of synthetic restorations based on a synthesis of scientific analysis and the artistic method (the Church of Peter and Paul on the Nice of the XIV century, restoration of 1955-1956, architect V.V. Kuvyrdin). The most fruitful are the restoration of multi-layered monuments, in which there is a departure from the principle of "optimal date" in favor of the preservation and disclosure of all valuable elements of different periods (Church of St. John the Baptist on the Flinders of the 12th-17th centuries, restoration of 1952-1953, architects T.V. Gladenko, L.M. Shulyak). The fundamental feature of the Novgorod restoration is the desire for reliability. A widespread use of the new method of analytical restoration "with exposure" is the installation of exposure probes for demonstrating ancient forms (Church of Mikhail the Archangel on the Fourteenth Century Trading, restoration 1957 - 1961, architect L.E. Krasnorechiev). For the first time, the disclosure of fragments of ancient elements was used, not their full volume, the full disclosure of the unplastered masonry characteristic of Novgorod churches (the Peter and Paul Church in Kozhevniki of the 15th century, restoration of 1955-1958, architects L.M. Shulyak, G.M. Pavement sign).

Many works of the 1960s. belonged to breakthroughs that outstripped the development of the domestic restoration and laid the foundations of new methodological concepts (the Church of Peter and Paul on the Fortress of the XII century, the restoration of 1960 - 1963, the architect G.M.Shtender; the Church of the Annunciation on the Myachin of the XII XVII centuries, restoration 1959 - 1961, architect L.E. Krasnorechiev). In works using fragmentary methods, the influence of Western principles of architectural restoration, which has intensified since the mid-1960s, is visible. (Puppies, 2004). The unique character, in which a vivid individual approach of the architect-restorer was manifested, was distinguished by the restoration of the Paraskeva Pyatnitsa Church on the Market of the beginning of the XIII century. (restoration of 1954 - 1962, architect G.M. Stender).

The formation of the Vladimir-Suzdal architectural and restoration school began in the post-war years with the creation in 1945 of the Vladimir restoration workshop. The work of the 1940s became important for the development of the Vladimir-Suzdal school. at the Dmitrievsky Cathedral of the XII century. in Vladimir using unique methods of engineering strengthening. Work on the Dmitrievsky Cathedral and other white-stone monuments of the region played a significant role in creating research methods, analysis, solving the issues of strengthening and restoration of monuments in the late 1940s - early 1950s. (architects A.D. Varganov, A.V. Stoletov). The methodology was based on improving the techniques and methods of archaeological research on the detection of full-scale remains of genuine elements, which provided the basis for the most complete reliable restoration of the lost parts of the monuments as part of fragmented restorations according to the analytical principle.

Works of the 1950s they were mainly examples of fragmented restorations using the analytical method (the Resurrection Church in Suzdal in 1720, restoration work in 1950, architect E.M. Karavaeva). The emergency state of the monuments and their parts required significant reinforcing measures (House of Sapozhnikov of the 17th century in Gorokhovets, restoration work of 1952, M.A. Firsov). Separate works were a kind of synthetic restoration based on a combination of analytical and stylistic approaches with the reconstruction of completely lost parts of the monument using typological analogues (ensemble of the Bishops' Chambers of the 15th and 18th centuries in Suzdal, restoration of 1950-1954, architect A.D. Varganov). The basis of restoration work of the 1950s. laid the principle of restoration of monuments in the complex as a single ensemble (a complex of 
architectural monuments of the Assumption Monastery in the city of Alexandrov, architect N.V. Sibiryakov).

One of the aspects of practical activity was the improvement of the methodology of restoration and strengthening of monuments of the Vladimir-Suzdal white-stone architecture of the XII - XIII centuries. The most important thing in it was the study of the structural features of structures, which made it possible to find both the causes of their destruction and methods of conservation. A direct relationship was revealed between the strength characteristics of ancient structures and their spatial and spatial organization. The decision on the degree of intervention during the restoration of the monument took into account cases when later alterations gave it greater durability, which spoke in favor of their preservation. One of the conditions of the scientific, methodological and practical approach to engineering strengthening was the maximum preservation of the ancient parts of the building, a minimum of openings and disassembly, combined with an increase in the strength and stability of fortified structures. When reinforcing, building techniques were used that were traditional for ancient buildings: the introduction of hidden connections made of metal and reinforced concrete in the places where they were usually arranged at monuments of a certain type.

Since the 1960s a transition to more complete holistic restorations with the restoration of the original appearance of the monuments became evident (the Cathedral of the Deposition of the Rizpozhensky in Suzdal of the 18th century, the restoration of 1962, the architect OG Guseva). At the same time, the understanding of the inconsistency of the approach, limited to facade restoration without adaptation of the building, has intensified, which gave motivation for the active inclusion of structures of the Old Russian period in modern life. The period from 1965 to the 1975 s. associated with the appeal to large-scale complex restorations (Christmas Kremlin Cathedral of Suzdal, XI - XII centuries, XIII century, restoration of 1964, architects I.A. Stoletov, M.M. Subbotina); The corps of fraternal cells of the XVII century. Spaso-Euthymius Monastery, restoration of 1968 1969, architects I.A. Stoletov, M.M. Subbotina, V.M. Anisimov, L.V. Anisimova). The element of recreating the lost volumes of the monument was more fully introduced (transition from the Bishops' Chambers to the bell tower and galleries in the Suzdal Kremlin, restoration of 1966 - 1967, architect A.D. Varganov).

The special role of the Vladimir Restoration School in the development of methodological approaches to research and analytical restoration lies in the formation of the principles for constructing the architectural form of the monuments of Vladimir-Suzdal white-stone architecture of the XII - XIII centuries, identified on significant research material. This principle made it possible to reconstruct the original appearance of the buildings and their lost parts distorted by the late restructuring (St. George Cathedral of the 13th century in Yuryev-Polsky, the Church of Boris and Gleb of the 12th century in Kideksha, Assumption Cathedral of the 13th century Knyaginin Monastery). In the practice of scientific and design work of the Vladimir restoration workshop, there is a noticeable appeal to the problem of identifying the initial forms of ancient structures by constructing one-time and similar architectural monuments based on metrological and proportional analysis.

The beginning of the development of the Leningrad restoration school is associated with the stage of a qualitatively new in scale and methods of work to recreate the appearance of the damaged city in the post-war period, which had no analogues in domestic practice. Unlike other regions of the country, restoration works have been widely deployed in Leningrad since the first post-war years. A significant influence on the formation and development of the Leningrad restoration school in the post-war period was exerted by systematic field work carried out during the war years and after the liberation of Leningrad and its suburbs. Restoration expanded the boundaries of narrow specialized activities on certain types of monuments, its elements were included in a single architectural and urban 
planning process. Restoration work in the historical center was a kind of urban restoration, preserving the appearance of the urban environment in the form prevailing before the military destruction.

The restoration work of the Leningrad restoration school of the post-war years covered a wide range of monuments. In relation to the monuments of palace and manor architecture of the XVIII - XIX centuries. the technique of their comprehensive restoration as complex and holistic works of art synthesis - architecture, sculpture, painting, landscape gardening and applied art — was being formed. For the first time in Russian practice, the ensemble principle was outlined, which consisted in the fact that the restored architectural object was not considered separately, but as an element of the environment in its natural historical variability. A particular task on the destroyed monuments was the determination of the limit of permissible recovery of losses.

The practice of the post-war years focused primarily on holistic restorations. A significant part of the work was the restoration of interiors with the restoration of a significant amount of painting, decorative stucco, sculpture, works of precious wood (Russian Museum, restoration 1945 - 1946; architects L.M. Anolik, G.A. Greenberg, K.D. Halturin). Features and state of the architectural heritage of Leningrad in the postwar period led to the development of methods for full or partial reconstruction, partial reconstruction. The reconstruction of ruined architectural monuments of Leningrad was recognized as radical by preserving the genuine, when the smallest genuine details formed the fabric of the recreated objects. The presence of typological analogues that correspond to certain chronological boundaries and fit into the framework of one architectural school, made it possible to partially or completely recreate the lost heritage.

One of the features of the Leningrad restoration is the very broad interpretation of the concept of "analogue" that has developed in it. This was explained by a number of factors: the specifics of the most complex forms of artistic decoration of monuments, an orientation toward holistic restoration. During restoration work with large volumes of recreation, there was a desire to preserve genuine fragments of painting and decoration (Winter Palace, Mining Institute). With the complete loss of individual details, recreation was recognized as necessary by analogy, the choice of which was primarily determined by the work of the architect - the author of the restored monument at other sites. However, often attracted analogues went back to other forms of art, including European (restoration of bas-reliefs in the interior of the Upper Bath pavilion in the Catherine Park in Pushkin, made by comparing with drawings of antique bas-reliefs of the Golden House of Nero in Italy).

In some cases, the methods of reconstruction went beyond the widespread use of analogues, acquiring a more free character of "co-creation" with the masters of the past. In such cases, the process of restoring the previous forms bordered on a new design "in the style" of the era that the monument belonged to (the Grand Palace in Peterhof, restoration of 1948-1958, architects V.M. Savkov, E.V. Kazanskaya). There were tendencies of combining elements of different eras in a restored multi-layered monument, documented restoration and hypothetical recreation on the basis of numerous analogues and iconographic materials, which led to unexpected methodological decisions (Kikina Chambers of the 18th century, restoration 1953-1956; architects V.M.Savkov , I.N. Benois). The method of fragmented restoration on the monuments of Leningrad was not widespread and was used in cases where the incomplete restoration of the lost did not violate the overall composition of the whole ensemble (the initial project for the restoration of the palace in Pavlovsk, head F.F.Oleinik).

A particular problem in the practice of Leningrad restoration was the question of the use of new materials. When reconstructing, interpreted as a visual imitation of lost forms, new durable and effective materials were used quite widely (Cell building of the Smolny Monastery, restoration of 1954, architect I.N. Benois). During restoration work on the preserved objects, the problem of reproducing old technologies and materials was given 
more significant significance. When performing decorative and artistic finishes, the rearrangement of the lost elements was carried out, if possible, in the old technique. A special achievement was the development of special technologies for strengthening, conservation and restoration of natural stone during the restoration of the most important monuments of urban planning heritage (St. Isaac's Cathedral, restoration of 1954 - 1963, leader A.L. Rotach).

The development of the tradition of the Leningrad restoration school was accompanied by the deepening of research methods and the expansion of practical capabilities, a palette of technological methods and restoration materials. On the one hand, a careful attitude to genuine material developed, the use of its informative properties and the desire for maximum authenticity (bastions of the Peter and Paul Fortress, restoration of 1963, architect I.N. Benois). Another direction led to a trend of bold reconfiguration by analogies in the absence of information about the true nature of the monument (Summer Palace of Peter I, restoration of 1957 - 1960s, architect A.E. Gessen). Large-scale unique activity was associated with the reconstruction of the interiors of suburban palaces (Catherine Palace in Tsarskoye Selo, restoration of the 1960s, architect A.E. Gessen).

Based on the traditional experience of pre-war restoration, the restoration and restoration activities of the Leningrad school significantly expanded the boundaries of its methods, partly bringing them closer to the principles of modern design.

The main vector of development of the Pskov restoration school was determined by the prevailing desire for holistic recreation - artistic restorations. This was partly influenced by local conditions associated with insufficient durability and fragility of the main material of the monuments. Works of the 1950s - 1960s were marked by a focus on restoring the original core of the monument in original forms or in forms corresponding to the period of the highest prosperity. This approach was implemented on a number of ancient monuments of church architecture, which were distinguished by a complex multi-volume spatial composition with layers of various historical periods (a double church of the Nativity and the Protection of the Virgin Mary of the 15th century, the author of the restoration project V.P. Smirnov). An element of hypothetical recreations was added according to analogues when restoring belfries, gable wooden coverings (the Church of St. Nicholas from Usoha, restoration of 1964-1965, the architect B.S. Skobeltsyn; the church of Peter and Paul from the Buoy of the 16th century, the restoration of 1962, the head of .A. Lebedev). Large-scale work in this direction was carried out during the restoration of the largest monument of serf architecture - the Pechersk Monastery Fortress (restoration of 1960-1968, the authors of the project M.I. Semenov, V.P. Smirnov). The reconstruction of the walls and towers of the fortress in full profile was due not only to the specifics of the building material (limestone), but also to the nature of their functioning as structures of the existing monastery. The expressed craving for artistic restorations was dictated by the desire to preserve the original Pskov architecture, to identify its stylistic integrity, a priority in relation to the historical informativeness of individual parts.

The opposite conservation trend in the Pskov restoration practice manifested itself in the unveiling of the remains of the stone monuments of Dovmontov city - seventeen church and civil buildings of the XII - XVI centuries. (restoration of 1962, leader V.D. Beletsky). A series of conservation measures with partial restoration, which made it possible to recover from the catastrophic state and preserve the ancient ruins from destruction, was carried out at large monuments of the region's monastic architecture (the Cathedral of St. John the Evangelist and the refectory church of the 16th -17 th centuries of the Krypetsk monastery, restoration 1962-1964, leader B.S. Skobeltsyn). 


\section{Results and Discussion}

A study of the leading schools of architectural restoration allows us to conclude that their formation took place in areas with prominent architectural schools, which had vivid features and represented separate layers of the development of Russian culture. The typological and architectural-artistic context had a direct impact on the features of the formation of architectural and restoration activities. The formation of restoration schools was based on the continuity of the traditions of pre-war restoration. The practice of regional restoration schools has demonstrated examples of both holistic and fragmented approaches, to some extent maintaining adherence to a particular method in different periods. At the same time, in the practice of individual schools, new methods and conceptual approaches were formed that brought the development of domestic restoration to a qualitatively new level. In the second half of the twentieth century. there was a certain leveling of the features of regional restoration schools. Work with the monument as a whole began to take on a more comprehensive character, expanding the range of various restoration approaches and techniques. The predominant direction of the leading restoration schools remained the desire for holistic restorations while preserving various layers of the monument at different times.

\section{Conclusions}

The study shows the significant contribution of leading domestic architectural and restoration schools to the development of scientific theory and practice of restoration in the twentieth century, as well as their impact on the architectural and restoration practice of the late XX - early XXI centuries. The development of regional restoration schools in the twentieth century. performed a significant role in preserving the architectural and urban planning appearance of Russian historical cities.

\section{References}

1. A. S. Shchenkov, Architectural heritage at the turn of the 20th and 21st centuries. Problems of restoration and heritage protection. 2nd edition (KRASAND, 2014)

2. K. V. Rytsarev, A. S. Schenkov, European restoration thought in the 1940-1980s (KomKniga, 2010)

3. A. S. Shchenkov, Monuments in the Soviet Union: Essays on the history of architectural restoration (Monuments of historical thought, 2004)

4. Yu. G. Bobrov, Theory of restoration of monuments of art: patterns and contradictions (Edsmith, 2004)

5. Yu. G. Bobrov, The philosophy of modern conservation and restoration. Illusions and reality (Art school, 2017)

6. A. A. Kedrinsky, Basics of restoration of architectural monuments (Fine art, 1999)

7. O. M. Kormiltseva, "Herald." Architect. 21st Century ", 2 (35), 16-21 (2010)

8. I. Kravtsova, Construction and urban management in St. Petersburg and the Leningrad Region 158, 59 - 64 (2015)

9. N. N. Kuzmina, O. N. Kovalenko, Novgorod and Novgorod land. Art and restoration, $6-25$ (2007)

10. B. M. Matveev, Deconstruction of architectural heritage ( $\mathrm{SPb} .:$ Polytechnic service, 2012) 
11. M.I. Milchik, From the Leningrad school of restoration to the St. Petersburg school of reconstruction. "Herald." Architect. 21st Century ", 2 (55) (2015)

12. I. A. Stoletov, A. N. Trofimov, N. A. Goryacheva, L.V. Dudorova, Vladimir-Suzdal School of Restoration. History, methods and practice of restoration of objects of historical and cultural heritage. Vladimir (2011).

13. N. D. Troskina, S. B. Kulikov, A. S. Podyapolsky, A. L. Batalov, M. L. Petrova, S.V. Demidov, D. N. Kulchinsky, L. A. Belova., N. V. Kamenev, Gathering stones, Central scientific and restoration design workshops. 65 years old (LLC ArtKom)

14. A.S. Shumilkin, Volga Scientific Journal 2, 101-106 (2019)

15. S.M. Shumilkin, Volga Scientific Journal 3, 106 - 113 (2019)

16. V. A. Yadryshnikov, The miracle of rebirth: The history of Novgorod architectural restoration $(\mathrm{SPb}$.: Publishing house "Kriga", 2017) 